epistemic

Engaging in

\title{
disobedience:
}

on the

\section{decolonialization of}

design discoupses

Mara Recklies 
Colonial-critical reflections on the basic principles of Western academic disciplines are a necessity that has attracted growing attention in the past few decades - mostly in postcolonial studies, but also in other disciplines and discourses. This is shown, for example, by the lively discussions in German sociology on cosmopolitical thinking and cosmopolitical studies (see Köhler 2007: 68). Ten years ago, the German sociologist Ulrich Beck and the political scientist Edgar Grande emphasized that, if consideration was given to the historical circumstances in which Western thinkers of the past laid the foundations of their disciplines, the academic identity of the research establishment - rooted in impartial work and objective scientific principles - clashed with «implicitly existing partiality» (Beck/Grande 2010: 208). After all, even if their universalist claims suggest otherwise, many theories of modernity are based on a «limited range of early modern national experiences» (Beck/Grande 2010: 189), which were acquired against the backdrop of the political rule over foreign territories, their economic appropriation, and the exploitation of their resources and populations.

The modern sciences and academic disciplines emerged in imperial conditions that continue to influence them today. This is clearly articulated in the decolonial discourses of Latin America, in which the entire Western episteme, as defined by the Peruvian sociologist Aníbal Quijano, is described as colonial (see Quijano 2000). In this context, "colonial» refers to the structural reproduction of specific colonialist patterns in culture, the economy and politics. Having survived colonial rule, these patterns continue today to determine interpersonal communication, social orders, thought, and perception (see Kastner/Waibel 2012: 11, 19). In Quijano's work, the critique of a form of coloniality that has been reproduced for centuries is accompanied by a fundamental critique of modernity. From this perspective, modernity and coloniality are not independent or successive, but mutually determinative (see Rath 2014: 99).

But what about a critical examination of the epistemic foundations of design? Is such an examination not urgently necessary, especially in relation to the academic disciplinization of design? And would it not be particularly important and influential in the field? After all, it could address the two different levels connected by design. The first is the practical level - design practice, the related production and distribution of goods, as well as their marketing, sale, use, and disposal. The second involves the theoretical examination of design that takes place in research and teaching in design studies, design theory, and the philosophy of design. Compared to 
1 Examples include the conference Beyond Change: Questioning the Role of Design in Times of Global Transformations, organized by the Swiss Design Network and hosted by the FHNW Academy of Art and Design, Basel, March 8-10, 2018; and the symposium Intersectional Perspectives on Design, Politics, and Power, organized by Decolonizing Design and hosted by the School of Arts and Communication, Malmö University, Sweden, November 14-15, 2016.

2 See, e.g., Designs for the Pluriverse by the Colombian-American anthropologist Arturo Escobar (2018). Escobar has been involved in joint research projects with Walter Mignolo, whose work is the focus of this chapter. (See, among others, Escobar/Mignolo 2013; Escobar 2018).

3 For example, the research group Decolonizing Design, founded in 2016.

4 Unless otherwise noted, all English citations of passages from this work are translations from the German version Epistemischer Ungehorsam: Rhetorik der Moderne, Logik der Kolonialität und Grammatik der Dekolonialität (Mignolo 2012). other disciplines, design philosophers and theoreticians began taking an interest in colonial-critical analyses of design practices and perspectives at a relatively late date. Even today, in design-related discourses, there is often a remarkably uncritical use of theorems whose foundations date to the late colonialist period. This would not always pose a problem if these theorems were handled with care and an awareness was raised for all they reproduce. While it is true that various studies have addressed the historical conditions in which many fundamental assumptions emerged, certain inhibitions seem to exist - particularly in German-speaking countries about resolutely tackling the coloniality of design. At the same time, there are a growingnumber of signs that this is changing. A variety of conferences, ${ }^{1}$ publications, ${ }^{2}$ and research groups ${ }^{3}$ are devoting themselves to the entanglements of design and coloniality and to the decolonization of design (see Fry/Kalantidou 2014; Design Philosophy Papers 15/1 [2017]; Design and Culture 10 [2018]).

The aim of this chapter is not to examine the colonial practices of design in an application context, but to engage in colonial-critical reflections on the episteme, or knowledge culture, of design (see Mareis 2011). This is a highly relevant topic because the episteme determines the concept and (self-)identity of design as a discipline Consistent with its (Western) cultures of knowledge, design uses rational principles to create functional, new and innovative artifacts and practices, thereby contributing to human progress and global developments.

\section{Epistemic disobedience}

It is particularly interesting to examine the reflections on the episteme of design in relation to the demands made by the Argentine literary scholar Walter Mignolo. In his work Desobediencia epistémica: retórica de la modernidad, lógica de la colonialidad y gramática de la descolonialidad, ${ }^{4}$ Mignolo explores how the dual concept of modernity / coloniality dominates and controls all forms of knowledge and cognition. He focuses not only on epistemology, but also on the Western appropriation of hermeneutics (comprehension) and aisthesis, 
5 Initial efforts are currently being made in German-speaking countries to define the basic features of a design aesthetic that will hopefully take the historicity of aesthetics into account. After all, a number of scholars - including the postcolonial feminist philosopher Madina Tlostanova - have identified the aesthetics of design as colonial in the sense that design has had a universalist, homogenizing effect from its very inception, prescribing rigid aesthetic principles and rejecting others (Tlostanova 2017: 3). Examples can be found in design manifestos ranging from the Bauhaus to functionalism as well as in the aesthetic trends and design principles of the present day, such as minimalism.

6 In another passage, Mignolo uses an axiom whose aim is to decentralize aesthetics: "You are and feel where you think» (Mignolo 2012: 99).

Here Mignolo also draws on Quijano's work (see Mignolo 2012: 52). or aesthetics (perception). He identifies these three fields as the pillars of a «colonial matrix of power» (Mignolo 2012: 49), which continues to be reproduced today. In his view, for example, aesthesis was transformed into a "sense of the beautiful and sublime» through the appropriation of imperial thought in the 18th century; in the process, the sublime increasingly receded into the background and the beautiful formed an aesthetic that uremained limited to the Western concept of art» (Mignolo 2012: 50). The introduction of strict principles governing what is beautiful and sublime, what is functional, and what is useless ultimately culminated in normative Western ideas about cultivated taste that always otherized «anything that fell through the coarse sieve of the normative Western/Northern aesthetics while presenting its local affective experience as universal» (Tlostanova 2017: 8; see also Sonderegger 2016; Leeb / Sonderegger 2016; Gikandi 2011). ${ }^{5}$

As a strategy for resisting the colonial matrix of power, Mignolo calls for «epistemic disobedience.» This is more than just an epistemological project directed against academic discourse. It is a form of disobedience that questions the established uregulatory systems and contexts of justification, as well as their power-based validity» (Kastner/Waibel 2012: 7). It is thus also directed against everyday Eurocentric thinking rooted in social institutions. Truth should be decentralized - this is the key idea expressed in Mignolo's dictum «I think where I am, $\|^{6}$ which he juxtaposes to the Western Cartesian axiom of «I think, therefore I am» (see Mignolo 2012: 122). Such decentralization transforms epistemic disobedience into a kind of «border thinking» that forms a «border epistemology» and is intended to facilitate a «delinking» (Mignolo 2012: 67) from the Western foundations of modern thought.? However, there is no "ontological exterior» or "purity untouched by modernity» at the center of border thinking; rather, there is an «exteriority that is conceived as both difference and dissent in relation to hegemonic discourse» (Kastner/Waibel 2012: 15). 
8 For a discussion of both the episteme and the archive in Foucault's work, see Frank (2004: 145-146). Among other things, Frank writes that the archive is a concept that replaces the episteme from Foucault's The Order of Things (1972b).
The archive

But how can this model of epistemic disobedience be applied to design - or, more precisely, to the study, theory, and philosophy of design? And how can we engage in epistemic disobedience? This chapter does not practice epistemic disobedience itself. Rather, it attempts to outline what the target of epistemic disobedience in design might be. For this purpose, I will draw not only on Mignolo's episteme concept, but also on Foucault's. In this context, what Foucault describes as an "archive» in his work Archaeology of Knowledge (Foucault 1972a: 128) can be taken as the equivalent of the episteme. ${ }^{8}$ After all, like the episteme, Foucault's archive describes a kind of "shigher unity» (Frank 2004: 146) from which discourses spring and which determines what can and cannot be said and thought in them. Hence, the archive is always located "at the very root of the statement, " defining in advance "the system of its enunciability» (Foucault 1972a: 129). For this reason, Foucault labels the archive «the general system of the formation and transformation of statements» (Foucault 1972a: 130). Discursive formations can only be contextualized by considering the episteme or the archive, because these define the formations" "conditions of existencely (Foucault 1972a: 28).

Thus, applied to design, epistemic disobedience as defined by Mignolo involves considering the colonially influenced origin of discourses. Although several recent philosophical studies of design have emphasized that it is only possible to understand design in terms of the modern design discourses from which it has emerged (see Feige 2018: 41ff., 86ff.; Parsons 2016: 54ff.), these modern discourses are often viewed and analyzed in an overly isolated fashion. Scant attention is paid to the colonial archive that determined their «conditions of existence.» However, if we consider the fact that both modernity and modernism are formations whose developments and worldviews would not have been possible without colonialism, the rule over other peoples, and the oppression and exploitation of these peoples, it is only logical to conclude that we cannot understand design only against the backdrop of industrialization and the rise of capitalism, but also need to consider colonialism and the imperialist ideology that constituted design's fundamental convictions, practices, and modi operandi. At the same time, the necessity to raise awareness of the archive of design discourses underscores the fact that decolonization is not - as is sometimes assumed - a question of decolonizing the colonized, «but also (and perhaps fundamentally) of decolonizing the colonizers» (Mignolo 2012: 65). Decolonization is 
9 In my opinion, the following three studies give focus to the discussion: Mareis (2011), Feige (2018), and Parsons (2016).

10 Feige also makes an ontological distinction in order to separate design from fields such as art. However, his design concept is much narrower than Fry's (see Feige 2017).

11 An extremely interesting examination of the isms of design from a postcolonial perspective can be found in Boehnert / Onafuwa (2016). thus a "dual activity» (Mignolo 2012: 77) that affects not only the oppressed but also the elites, who have thus far enjoyed an «epistemic privilege» (Mignolo 2012: 78).

The isms

However, before taking a closer look at the epistemic coloniality of design, I would like to address a few possible conceptual ambiguities. The different understandings of design make it enormously difficult to speak of the coloniality of design or its knowledge culture without clarifying the term «design.» After all, design can be grasped as a two- or three-dimensional fashioning of things or as an "aesthetic practice,» as the German philosopher Daniel Feige (2018) and the cultural sociologist Andreas Reckwitz (2012) have suggested (even if their views are not identical). Others have defined design as an almost universally applicable planning and drafting discipline - a view that has frequently been encountered in design research since the 1970s (see Rittel 1992). ${ }^{9}$ Further complicating matters is the concept of ontological design introduced by the philosopher Tony Fry ${ }^{10}$ and widespread in the discourse on decolonization. Fry describes ontological design as "a way of understanding the dynamic designing relations between the world, things and human beings» (Tlostanova 2017: 52). This concept of design is often informed by the idea of the control over and disciplinization of human perception and interpretations of the world. It transforms design into a uset of specific ontological, epistemic and axiological notions imposed forcefully onto the whole world, including its peripheral and semiperipheral spaces in which alternative versions of life, social structures, environmental models or aesthetic principles have been invariably dismissed» (Tlostanova 2017: 3). In Local Histories / Global Designs: Coloniality, Subaltern Knowledges, and Border Thinking, Mignolo (2000) advances an equally broad concept of design. He stylizes the dual principle of modernity / coloniality into a «global design» (Mignolo 2000: ix) that shapes and determines the relationship between the world, things, and human beings. In my opinion, though, we do not need such an expanded concept to grasp the coloniality of design. A more conventional understanding of design, centered on, say, the fashioning of objects and interfaces, can be used to illustrate the colonial impregnation of the episteme. Unfortunately, there have been few design studies to date that clearly identify themselves as epistemologies and focus not 
12 When distinguishing the different paradigms in Kuhn's work, Fallan refers to Masterman (1970), who identifies a total of 22 different Kuhnian paradigms. Fallan's discussion is limited to the abovementioned metaphysical paradigm and to the «sociological» and «artefact paradigms» (see Fallan 2010: 134; and Kuhn 1967). on the practice of design, but on the question of the knowledge it employs (see Parsons 2016: 35ff.).

One exception is a study by the Swedish design historian Kjetil Fallan, who emphasizes the difference between the episteme of design and the «isms» crystallizing out of it." Even though this study does not operate within a postcolonial or decolonial analytical framework, it is extremely helpful, as it allows us to develop an understanding of the target of disobedience. Fallan is yet another scholar who draws on the episteme in a Foucauldian sense, which does not refer to knowledge, scientific findings, or the truth they contain, but rather to the conditions in which they emerge - to those things that determine the potential for producing knowledge and findings. In the process, Fallan emphasizes the significance of the episteme for the formation of «isms»:

The epoch's slowly but ever changing episteme both restricts and affords what is possible to say, think, comprehend and do at any given time. This is where the rules that constitute people's action come into being. Here, the situations in which institutions are embedded arise. This is the background against which every new ism takes shape. (Fallan 2010: 114)

Applied to design, this means that its isms (e.g. functionalism, constructivism, postmodernism, and minimalism) emerge from the episteme. According to Fallan, they reflect the values and worldviews of the episteme, but may also enter into a dialogue with, or even rebel against, these values and worldviews, because their relationship is marked by reciprocity: while the conditions for the isms are determined by the episteme, the episteme itself may be changed by the isms' development.

An important feature of the isms is that, while they have a dogmatic and manifesto-like character, they are detached from the objective logic of scientific theories. They have a normative effect and «tend to propose or dictate how art/architecture / design should be» (Fallan 2010: 116). Even if the isms of modern design pretend to be - or are even viewed as - rationally based theories, they differ from such theories. In fact, they are disguised ideologies. Fallan suggests that a few of the isms that produce particularly potent ideologies should be seen as metaphysical paradigms as defined by Thomas Kuhn (1967).12 In fact, they have many common characteristics: «The metaphysical paradigms correspond to isms [that describe] a world view, a set of beliefs, a metaphysical speculation, a new way of seeing or an organizing principle.»l The isms with the power to 
become worldviews are primarily those affiliated with the grand epochs of the past, especially uthe dominant world view of the twentieth century - modernism» (Fallan 2010: 134).

This passage makes clear that the isms correspond to what Mignolo has described as the "colonial matrix of power» - namely, "a web spun of beliefs, against whose backdrop action is taken and rationalized» (Mignolo 2012: 50). But it is precisely to these modernist ideologies that scholars such as the Canadian philosopher Glenn Parsons assign a leading role in shedding light on contemporary design. «Modernism supported a rational conception of Design ... it offered a reinterpretation of some of the key criteria of design - the functional, the symbolic and the mediating - and rejected certain other interpretations of them as irrelevant» (Parsons 2016: 54).

This raises the question of why certain, non-rationally based ideologies and theorems are able to continue to exist in design and why they are not later exposed and cast aside as ideologies. Fallan believes that they are not recognized because they are not articulated. Not only the artifacts themselves, but also the practice of design and its theoretical reflections conceal them as «cultural modes» (Fallan 2010: 117). In summary, the entire culture of design can be understood as the "co-production of ideology and practice» (Fallan 2010: 118).

\section{The new}

The preference for functionalist, sleek, emphatically industrial design began at the turn of the 20th century. Even today, it ensures that functionality and efficiency are seen as crucial aspects of design. However, contrary to common assumptions, this focus is not based on rational, calculative considerations, but aesthetic-ideological ones. Several years ago, this was pointed out by the German design historian Gert Selle, who stressed that the sleek style of modern mass-produced products was a manifestation of «the rationality of industrial production and capitalist value creation» (Selle 2007: 107). These relations had far-reaching consequences for design because in the period that followed, anything that was «directed against the principle of functional aesthetics» suddenly seemed «irrefutably backward» (Selle 2007: 108). Leading manufacturers no longer regarded themselves as producers, but as social and cultural political institutions that engaged in an aesthetic pedagogical practice. "Current aesthetic-cultural and educational questions, as well as questions regarding the social aspects of art, are being discussed against the backdrop of industrial development, 》 Selle summarized. «Functional, material-compatible design» is presented as an act of «truthfulness» 
13 Translation by Adam Blauhut. For more on rhetoric in the work of Loos and his contemporaries, see Makiuika (2010).

14

English translation from Mignolo (2007: 477). and, even more, as «a moral achievement» (Selle 2007: 115).

However, one can only understand the conceptual superiority of the rationality expressed in design, as well as the primacy of the «new, $\rangle$ if it is examined in relation

to the late colonial view of the world and the accompanying hierarchies of modernity. After all, both the new and newness are «key rhetorical concepts of modernity» (Mignolo 2012: 138). The idea of the superiority of the new embodies the spirit of modernism, which went hand in hand with - and was practically rooted in - an unconditional belief in progress and development. «Modernism can be seen as a constant quest for modernity, or the wish to establish an anti-traditional tradition, $)$ writes Fallan (2010: 111). In this passage, though, Fallan does not mention that the modernist devaluation of the «traditional» involved a segregative devaluation of colonized societies, which were seen as traditional. In the logic of modernity, utraditional» signifies nothing more than «backward in comparison to their European and American counterparts» (Beck/Grande 2010: 189). Here, «backward» and «underdeveloped» are not meant only in an industrial and economic sense, as Mignolo emphasizes, but also uintellectually and epistemically» (Mignolo 2012: 125). The self-understanding of modernity as progressive would not have been possible without assigning uprimitives» and "barbarians» to the realm of the traditional, thereby establishing a chronological «before» (see Mignolo 2012: 121-122).

Such a segregative approach to modern design is clearly evident in Adolf Loos' racist essay "Ornament and Crime» (1908), which Parsons, among others, has described as constitutive of the selfunderstanding of design (see Parsons 2016: 59ff.). One of the more influential sentences in Loos' text reads: "The evolution of culture is equivalent to the removal of ornament from everyday objects» (Loos 1962: 277)..$^{13}$

This primacy of the new, which is dependent on a separation from what is purportedly outdated, continues to be reproduced in consumer culture today. In it, quality is always assessed or promoted as "the first or the best in a specific category," as Mignolo puts it; or it is based on the idea of «producing or buying the best in a specific product line» (Mignolo 2016: 138). Even today, it remains problematic that «the celebration of newness and change» - which applies particularly to design, but is not limited to it - "shadows the consequences of such changes 14 $^{14}$ (Mignolo 2012: 139; original emphasis).

However, colonial thinking is perpetuated not only by the primacy of the new, the idea of the superiority of progress, and the devaluation of everything «old» and «non-Western,» but also by 
15 The failure of these models in practice shows the strong opposition to forced collectivity: the occupants of the constructivist housing developments remodeled almost all of what remained of them. They refused to spend their lives in predesigned public spaces such as communal cafeterias and washrooms, and often installed private bathrooms, kitchens and balconies in their units (see Tlostanova 2017: 3).

16 This subheading is taken from Dilnot et al. (2015: 122). design's universalist claim that it can optimize any object and thus contribute to the development of the world and to continuous progress.

From the start, design's colonial hubris was reflected in the fact that it repeatedly served modern utopias or played a key role in producing them. Both Russian constructivism and the Bauhaus were driven by providential, messianic motives. They promised new social forms, lifestyles, and even the development of new human beings, which shows their proximity to the ideas of social and biological engineering (see Groys / Hagemeister 2005). An early example is Soviet constructivism, which sought to create an ideal collective environment that through a series of controlled rituals aimed to form a perfect human who enjoyed a predetermined happiness ${ }^{15}$ (see Tlostanova 2017: 3). Modernity's supposed progressiveness finds correspondence in the teleological narratives of design, which were written by scholars such as the design historian Nikolaus Pevsner (see Pevsner 1957). According to these narratives, design underwent a strict development that contributed to the continual development and bourgeoning of society. Although these narratives have since been exposed as hair-raising constructs (see, among others, Breuer 1998: 14-15), the tendency to glorify or «black-box» (Fallan 2010: 127) the isms at work in design has lived on to the present day. A tragic example can be seen in the large number of wellmeant but counterproductive design projects that seek to provide aid to the formerly colonized regions of the world and have raised the much-debated question of whether humanitarian design is not the new imperialism (see Nussbaum 2010).

«Another history, another designing?» 16

Yet how can or must Mignolo's demand be fulfilled using colonialcritical archaeological analyses? Is an explication of design's modern and thus late colonial origins all that is needed to uncover the «liberating perplexities of the identity-related process of self-affirmation» (Kastner/Waibel 2012: 40), which is said to characterize decolonial thinking and its corresponding practices? Is it possible to «disobey» the episteme of design?

There is often little agreement on this question, especially because the concept of epistemic disobedience is itself seen in a critical light. It has, for example, been pointed out that the different 
17 However, in other passages - e.g. with respect to demanded «delinking» - Mignolo refers to Foucault: «Delinking and changing the terms of the conversation means, among other things, to fracture the naturalized assumption that links words and things, as Foucault taught us» (Mignolo 2007: 505, n. 27). Köhler describes such approaches as a «paradoxical appropriation of the West,» in which «Eurocentric institutions and methods of rule» are «used by subalterns as a weapon against Western hegemony» (Köhler 2007: 113).

18 English translation from Mignolo (2007: 485). forms of epistemic disobedience are not new or unknown (see Aster 2014: 106). Social struggles for liberation and the corresponding historiographical narratives have always intervened in existing orders of knowledge, their representational logic, and their modes of subjectivation. In addition, argue critics, it is problematic to speak of Western thinking as if it were a uhomogeneous entity» that "has hardly been questioned in terms of its Eurocentric content» (Aster 2014: 106). A similar objection is that the construction of a dichotomy between European / colonialist knowledge systems and non-European / colonialized ones is in fact a characteristic feature of European modernity (Blome 2014: 110-111). Finally, the critiques of Mignolo's thinking often emphasize that a certain skepticism about (re)essentializations of "other» formations of knowledge is in order, because, as Donna Haraway explains, there is a «serious danger of romanticizing and / or appropriating the vision of the less powerful while claiming to see from their positions. To see from below is neither easily learned nor unproblematic (Haraway 1991: 191).

Does this mean that epistemic disobedience is a concept that cannot be implemented in theoretical and philosophical practice? In recent years, a growing number of design publications have examined indigenous ways of knowing and learning and juxtaposed these to Western concepts (e.g. Tunstall 2013). Occasionally, they have also developed design concepts that make cosmopolitical claims (e.g. Yaneva / Zaera-Polo 2017). Furthermore, a form of history-writing is underway that is not Eurocentric in focus and is attempting to arrive at a more conscious way of dealing with nationalisms (e.g. Fallan 2010; Dilnot et al. 2015). However, even if all of these endeavors ultimately bring about a paradigm shift, Mignolo doubts that an epistemic break or a paradigmatic turn in Kuhn's sense could ever lead to decolonial thinking. ${ }^{17}$ "The de-colonial shift belongs literally to a different space," he writes, "to the epistemic energy and the lack of archive that has been supplanted by the rumor of the dis-inherited» (Mignolo 2012: 170). ${ }^{18}$ This is one reason, he concludes in another passage: «lt is not enough to condemn the rhetoric of modernity and its complicity with the logic of coloniality» (Mignolo 2012: 168).

That said, Western philosophy and its disciplines should not be condemned in a rash, blanket manner, even if - viewed against the backdrop of Western philosophical practice - it does in fact seem impossible for us to find our way out of the colonial matrix by our 
19 Apart from these obstacles, a discussion in Design in the Borderlands (Fry/Kalantidou 2014) emphasizes the great difficulty of reaching an understanding in this discourse, despite all the good intentions. Addressing Mignolo, the editors ask, «Border Thinking and border epistemology assert the imperative of «thinking the others. Does this staking a position> presume an existence, or possibility, of «betweenness s as the locus of (both) the one and the other?» (Fry/ Kalantidou 2014: 173). Mignolo denies this, explaining, «The <in-between is a concept of modern and postmodern epistemology, not of border epistemology» (Fry/Kalantidou 2014: 174). Under the heading «Are we talking about the same thing?» Fry then responds, saying, «certainly we do not share the same understanding of 〈betweenness〉; it is not the same as <in-between but an ontology of non-binary oscillation (movement within the contradiction rather than between contradictory positions)»(Fry/Kalantidou 2014: 185). own efforts and methods. If the demand for decolonization leads to a decolonialism with a universalist claim, its ideologies and worldviews will merely replace the established isms with new ones. And if the appeal for epistemic disobedience results in the expectation of obedience to disobedience, it will lose credibility. The frequently entrenched divisions and oppositions in postcolonial studies and decolonial thought suggest such tendencies. They often result in inhospitable discourses in which the strict rejection of colonially impregnated terms, structures, and concepts restricts thinking and makes communication difficult or even impossible. ${ }^{19}$

At the same time, it is frequently overlooked that the conventions of the research system call for unew knowledge to be linked to existing bodies of knowledge» (Schmidt 2012). If the power of such conventions is not realized or taken into account - which can of course mean their violation, subversion, or instrumentalization - the concept of epistemic disobedience will remain nothing more than an appeal.

However, Mignolo was also aware of all of these difficulties. In his eyes, the task of identifying the complicity of Western research and disciplines with coloniality was thus «necessary, » even if «insufficient» (Mignolo 2012: 168). So, even from Mignolo's perspective, the above criticism is no reason to reject a deeper engagement with his work or, more importantly, with the idea of decolonial epistemic disobedience. At the least, a colonial-critical examination of the episteme of design can help ensure that Western theories are finally viewed in a global context - that is, that modern / colonial historywriting is reappraised and, if necessary, reinterpreted (Fuchs 2014 109). This is urgently needed, as the decolonization of the episteme is not a problem that is confined to intellectual elites or specific disciplines in cultural studies and the humanities. If decolonialization were viewed in this way, it would be robbed of its «cognitive explosiveness》 (Schmidt 2012), and the power of colonialism over current global conditions would be underestimated.

So what tasks are linked to showing that the episteme is colonially impregnated, as I have outlined in this text? Mignolo writes that the aim of decolonization is to eliminate the «monoculture» of modern thought, by which he means «the totality of the grand narratives of Western civilization» (Mignolo 2012: 67). Thus, epistemic disobedience 
could entail developing other understandings of design - for example, imagining a type of design whose superiority does not arise from exaggerating the new, the innovative, or the efficient, which allows for a pluralist aesthetics and abandons its universalist claims and messianic gestures. We are currently just beginning to discover and negotiate how this type of design can be imagined and practiced. 
Aster, Felix (2014): «Präfixe, Angrenzungen, Solidarität.»

ZfK - Zeitschrift für Kulturwissenschaften 1/2014,

Bielefeld: Transcript, pp. 106-108.

Beck, Ulrich / Grande, Edgar (2010): «Jenseits des methodologischen Nationalismus. Außereuropäische und europäische Variationen der Zweiten Moderne.») Soziale Welt 61, pp. 187-216.

Blome, Eva (2014): «Hochschulen als Orte des epistemischen Ungehorsams?» ZfK - Zeitschrift für Kulturwissenschaften 1/2014, Bielefeld: Transcript, pp. 110-111.

Boehnert, Joanna / Onafuwa, Dimeji (2016): «Design as Symbolic Violence: Reproducing the 〈isms + A Framework for Allies.n Lecture at the symposium Intersectional Perspectives on Design, Politics and Power, School of Arts and Communication, Malmö University, November 14 \& 15, 2016, http://www.decolonisingdesign.com/wp-content/ uploads/2017/06/Boehnert_Onafuwa_Design-asSymbolic-Violence.pdf.

Breuer, Gerda (1998): «Universalistische Erneuerung im Dienste des Verzichts. Eine Hinführung zum Kompendium der Texte.» In: Ulrich Conrads / Peter Neitzke (eds.), Ästhetik der schönen Genügsamkeit oder Arts \& Crafts als Lebensform: Programmatische Texte, erläutert von Gerda Breuer, Braunschweig/Wiesbaden: Vieweg, pp. 9-60.

Frank, Michael C. (2004): «Kolonialismus und Diskurs: Michel Foucaults (Archäologies in der postkolonialen Theorie.» In: Susanne Kollmann / Kathrin Schödel (eds.), PostModerne De/Konstruktionen: Ethik, Politik und Kultur am Ende einer Epoche, Münster: LIT Verlag, pp. 139-155.

Fry, Tony (2017): «Design for/by (the Global Southı.» Design Philosophy Papers 15/1, pp. 3-37.

Fry, Tony / Kalantidou, Eleni (2014): «An Exchange: Questions from Tony Fry and Eleni Kalantidou and Answers from Walter Mignolo.» In: Tony Fry / Eleni Kalantidou (eds.), Design in the Borderlands, London/ New York: Routledge, pp. 173-188.

Fuchs, Rebecca (2014): «Jenseits der Grenzen des epistemischen Ungehorsams.) ZfK - Zeitschrift für Kulturwissenschaften 1/2014, Bielefeld: Transcript, pp. 108-109.

Gikandi, Simon (2011): Slavery and the Culture of Taste, Princeton, NJ/Oxford: Princeton University Press.

Groys, Boris/Hagemeister, Michael/von der Heiden, Anne (eds.) (2005): Die Neue Menschheit: Biopolitische Utopien in Russland zu Beginn des 20. Jahrhunderts, Frankfurt am Main: Suhrkamp.

Haraway, Donna (1991): Simians, Cyborgs, and Women: The Reinvention of Nature, New York: Routledge.

Dilnot, Clive / Fry, Tony / Steward, Susan (2015): Design and the Question of History: Design, History, Futures, London: Bloomsbury.

Escobar, Arturo (2018): Designs for the Pluriverse: Radical Interdependency, Autonomy and the Making of Worlds, Durham, NC/London: Duke Press.

Escobar, Arturo/ Mignolo, Walter (eds.) (2013): Globalization and the Decolonial Option, London/ New York: Routledge.

Fallan, Kjetil (2010): Design History: Understanding Theory and Method, London / New York: Bloomsbury.

Feige, Daniel Martin (2018): Design: Eine philosophische Analyse, Berlin: Suhrkamp.

Foucault, Michel (1972a): The Archeology of Knowledge and the Discourse on Language, trans. A. M. Sheridan Smith, New York: Pantheon Books.

Foucault, Michel (1972b): Die Ordnung der Dinge, Frankfurt am Main: Suhrkamp.

Kastner, Jens / Waibel, Tom (2012): «Einleitung: Dekoloniale Optionen.»I In: Walter D. Mignolo (ed.), Epistemischer Ungehorsam: Rhetorik der Moderne, Logik der Kolonialität und Grammatik der Dekolonialität, Vienna / Berlin: Turia + Kant, pp. 7-42.

Köhler, Benedikt (2007): Soziologie des neuen Kosmopolitismus, Berlin: Springer.

Kuhn, Thomas (1967): Die Struktur wissenschaftlicher Revolutionen, Frankfurt am Main: Suhrkamp.

Leeb, Susanne/ Sonderegger, Ruth (2016): «Plädoyer für eine kulturwissenschaftliche Ästhetik aus Perspektive der Cultural Studies.n Kulturwissenschaftliche Zeitschrift 1/2016, De Gruyter, pp. 56-62.

Loos, Adolf (1962): «Ornament und Verbrechen.» In: Adolf Loos, Sämtliche Schriften Bd. 1, herausgegeben von Franz Glück, Vienna/ Munich: Herold, pp. 276-288.

\section{References}


Makiuika, John V. (2010): «Adolf Loos and the Aphoristic Style: Rhetorical Practice in early Twentieth-Century Design Criticism.» In: Richard Buchanan/Dennis Doordan / Victor Margolin (eds.), The Designed World: Images, Objects, Environments, Oxford: Berg Publishers, pp. 72-82.

Mareis, Claudia (2011): Design als Wissenskultur: Interferenzen zwischen Design- und Wissensdiskursen seit 1960, Bielefeld: Transcript.

Masterman, Margeret (1970): «The Nature of a Paradigm.» In: Imre Lakatos / Alan Musgrave (eds.), Criticism and the Growth of Knowledge: Volume 4: Proceedings of the International Colloquium in the Philosophy of Science, London, 1965, Cambridge: Cambridge University Press, pp. 61-65.

Mignolo, Walter D. (2000): Local Histories/Global Designs Coloniality, Subaltern Knowledges, and Border Thinking, Princeton, NJ: Princeton University Press.

Mignolo, Walter D. (2007): «DELINKING - The Rhetoric of Modernity, the Logic of Coloniality and the Grammar of De-coloniality.» Cultural Studies 21/2-3, pp. 449-514.

Mignolo, Walter D. (2012): Epistemischer Ungehorsam: Rhetorik der Moderne, Logik der Kolonialität und Grammatik der Dekolonialität, aus dem Spanischen übersetzt und eingeleitet von Jens Kastner und Tom Waibel, Vienna/Berlin: Turia + Kant.

Nussbaum, Bruce (2010): «ls Humanitarian Design the New Imperialism?» June 7, 2010, https://www.fastcodesign.com/1661859/ishumanitarian-design-the-new-imperialism.

Parsons, Glenn (2016): The Philosophy of Design, Cambridge: Polity Press.

Pevsner, Nikolaus (1957): Wegbereiter moderner Formgebung: Von Morris bis Gropius, Hamburg: Rohwolt.

Quijano, Aníbal (2000): «Colonialidad del Poder y Clasificacion Social..n Journal of World-Systems Research 6/2, pp. 342-386.
Rath, Gudrun (2014): «Debatte: Zur Praxis des sepistemischen Ungehorsamsı.» ZfK - Zeitschrift für Kulturwissenschaften 1/2014, Bielefeld: Transcript, pp. 99-100.

Reckwitz, Andreas (2012): Die Erfindung der Kreativität: Zum Prozess gesellschaftlicher Ästhetisierung, Berlin: Suhrkamp.

Rittel, Horst W. J. (1992): Planen, Entwerfen, Design, herausgegeben von Wolf D. Reuter, Stuttgart: Kohlhammer.

Schmidt, Volker H. (2012): «Epistemologische und methodologische Herausforderungen globaler Modernität..) SozBlog. Blog der Deutschen Gesellschaft für Soziologie (DGS), September 2012, htatp://soziologie.de/ blog/2012/09/epistemologische-und -methodologischeherausforderungen-globaler-modernitat.

Selle, Gert (2007): Geschichte des Design in Deutschland, aktualisierte und erweiterte Neuauflage, Frankfurt/ New York: Campus.

Sonderegger, Ruth (2016): «Zur Kolonialität der europäischen Ästhetik, ln Lecture at Fernuniversität Hagen, December 8, 2016, https://www.fernuni-hagen.de/ videostreaming/ksw/forum/20161208.shtml.

Tlostanova, Madina (2017): «On Decolonizing Design.» Design Philosophy Papers 15/1, pp. 51-61.

Tunstall, Elizabeth (Dori) (2013): «Decolonizing Design Innovation: Design Anthropology. Critical Anthropology, and Indigenous Knowledge..l In: Wendy Gunn / Otto Ton/Rachel Charlotte Smith (eds.), Design Anthropology: Theory and Practice, London/ New York: Bloomsbury.

Yaneva, Albena/Zaera-Polo, Alejandro (2017): What Is Cosmopolitical Design? Design, Nature and the Built Environment, London / New York: Routledge. 
